\title{
The Role of Allergy in Severe Asthma
}

\author{
Joshua L. Kennedy, MD ${ }^{1}$, Peter W. Heymann, MD ${ }^{1}$, and Thomas A. E. Platts-Mills ${ }^{1,{ }^{*}}$ \\ ${ }^{1}$ University of Virginia Asthma and Allergic Diseases Center, Charlottesville, Virginia
}

\section{Summary}

The classification of asthma to identify forms which have different contributing causes is useful for all cases in which the disease requires regular treatment, but it is essential for the management of severe asthma. Many forms of the disease can occur, and complex mixtures are not uncommon; here we artificially separated the cases into four groups: i) inhalant allergy, ii) fungal sensitization with or without colonization (including ABPA); iii) severe sinusitis with or without aspirinexacerbated respiratory disease (AERD), and iv) non-inflammatory cases, including those associated with severe obesity and vocal cord dysfunction (VCD). The reason for focusing on these groups is because they illustrate how much the specific management depends upon correct classification. Inhalant allergy can present as chronically severe asthma. However, severe attacks of asthma requiring hospital admission can occur in cases which are generally only mild or moderate. The best recognized and probably the most common cause of these acute episodes is acute infection with a rhinovirus. Recent evidence suggests that high titer IgE, particularly to dust mite, correlates to exacerbations of asthma related to rhinovirus infection. While it is well recognized that the fungus Aspergillus can colonize the lungs and cause severe disease, it is less well recognized that those cases may not have full criteria for diagnosis of ABPA or may involve other fungi. Identifying fungal cases is important, because treatment with imidazole antifungals can provide significant benefit. Taken together, specific treatment using allergen avoidance, immunotherapy, anti-IgE, or antifungal treatment is an important part of the successful management of severe asthma, and each of these requires correctly identifying specific sensitization.

\section{Introduction}

The public definition of "allergy" includes the implication that affected individuals are in some sense aware that they are allergic to something. However, for many or most of the allergens that are relevant to asthma, this relationship is not obvious. Thus, many patients with asthma are not aware that they are allergic to dust mites, cockroaches, or fungi, and certainly not aware of the role that these allergens play in their disease. When mite fecal particles were identified as the form in which mite allergens are inhaled, it was suggested that inhaling a few $(\sim 100)$ such particles per day was "the ideal way to increase both inflammation in the lungs and chronic bronchial hyperreactivity (BHR) without the patient being aware of the relationship" [1-3]. It was this and Roger Altounyan's evidence about seasonal increases in BHR related to pollen exposure which led to the studies where miteallergic patients who required repeated steroid bursts were admitted to a mite-free hospital unit to follow changes in BHR over months [4, 5]. A similar "experiment" was going on in Davos where mite-allergic children from the Netherlands spent a year in a mite-free sanatorium [6]. The results established that BHR is a reversible phenomenon and strongly supported the view that inhaling mite allergens can be a significant cause of BHR and can contribute to severe asthma $[2,5,6]$.

\footnotetext{
*Corresponding author: Dr. Thomas Platts-Mills, PO Box 801355, Charlottesville, VA 22911, tap2z@virginia.edu.
} 
The definition of severe asthma is not straightforward. According to EPR3, severe asthma is defined in adults and children as asthma symptoms "throughout the day," night-time awakenings 7 nights per week, the use of SABA several times per day, "extreme" limitation of daily activities, requiring oral corticosteroids $>2 \times /$ year, and spirometry with FEV $1<60 \%$ (7). The Severe Asthma Research Program's definition includes much less severe disease based on major criteria, the use of high dose inhaled corticosteroids and/or daily oral corticosteroids, and seven minor criteria ( 2 or more) including treatment with a daily oral controller medication, short-acting bronchodilator use, FEV1 < 80\% predicted at baseline, one emergency department visit, three oral corticosteroid bursts, history of worsening symptoms with a reduction in corticosteroid dose, and history of intubation [7]. Clearly, it is difficult to define the population of patients who have "severe asthma," and further, these definitions focus mainly on symptoms. More relevant here, none attempt to define causality of severe asthma.

As we have discussed, the severity of asthma can be defined in many different ways, but in most models the classification is at least in part influenced by the response to treatment. Thus, a patient who has normal lung function and minimum symptoms while taking high dose inhaled steroids plus a long-acting $\beta 2$-agonist (LABA) may or may not be regarded as severe [7-9]. There are also important differences between the patterns of severe disease in children and adults. In children (age 3-18), chronically severe disease is rare, but many children with moderate or even mild asthma can have severe episodes triggered by rhinovirus (RV) infections [10-13]. Up to age 13, conditions such as vocal cord dysfunction (VCD) or allergic bronchopulmonary aspergillosis (ABPA) are so rare that they are often ignored; however, they need to be considered in teenagers. In addition, there is a wide range of causes of severity, some of which include a role for allergens while others do not (Table 1) [14-16]. The important feature here is that the different causes have major implications for treatment. Thus, allergen avoidance or immunotherapy has only been shown to be relevant in patients who are sensitized to inhaled allergens [17]. Equally, the use of antifungal agents is generally only considered for patients who are colonized with fungi [18-20].

There is another way in which treatment is relevant to the evaluation of severity. If a widely used treatment, such as high dose inhaled steroids with or without LABA is most effective in the treatment of cases with inflammation caused by inhaled allergens, then these cases will become less common or rare among patients in a tertiary care asthma clinic. In general, we regard eosinophils and eosinophil products such as ECP or expired nitric oxide (eNO) as evidence of a role for a Th2 response to foreign antigens. Expired nitric oxide is well known to correspond with eosinophilia, and this eosinophilia most often means that there is also an $\operatorname{IgE}$ antibody response [21, 22]. However, it is always possible that eosinophilia, particularly that associated with sinusitis, is related to a Th2 response without or with minimal $\operatorname{IgE}$ production. Some recent reports have suggested that the bronchi of severe asthmatics have a neutrophil-rich exudate [23]. However, Taylor and his colleagues in New Zealand provided strong evidence that the presence of neutrophils in induced sputum is primarily an effect of inhaled steroids [21]. Although those patients predominantly had moderate rather than severe asthma, the principle, i.e. that inhaled steroids can increase the number of neutrophils in the lungs, is relevant to severe asthma. Oral steroids can rapidly reverse an eosinophil response in the peripheral blood and increase neutrophils. In this article, we will consider i) the role of inhaled allergens in severity, ii) the role of colonizing fungi, iii) the relevance of sinus disease, and finally, iv) a group of predominantly non-allergic conditions of the upper airway including the vocal cords. 


\section{Inhaled allergens, wheezing, and severity}

\section{What is natural exposure?}

Following the initial evidence about the effects of seasonal exposure on BHR, Hargreave and his colleagues in Hamilton demonstrated that allergen provocation could produce an increase in BHR lasting for several days or weeks [24, 25]. Those experiments provided further evidence that allergen exposure could cause inflammation of the lungs and increase BHR. On the other hand, provocation using $10^{-8}$ droplets of approximately 2 micron diameter that have an allergen concentration of $2-20 \mu \mathrm{g} / \mathrm{ml}$ is not a model of natural exposure. Our estimates of exposure to mite feces or pollen grains suggest that approximately 100 particles enter the lungs per day and that these particles are 20 microns in diameter and have a concentration of allergen close to $1 \mathrm{mg} / \mathrm{ml}[2,26]$. Thus, daily natural exposure is nearly a million-fold fewer particles than a 5 minute bronchial provocation, but each particle contains about 100,000 times more allergen! Despite many attempts, it has proven very difficult to make an exposure chamber where large particles are airborne as a realistic model of natural exposure. It is often argued that entry of particles into "the lungs" is primarily related to particles $\mathbf{S}$ microns in diameter. This might be taken to suggest that cat dander and the spores of Penicillium or Aspergillus would be more effective at causing asthma; however, there is in fact no cut-off of size for entering the bronchi (up to the size of a peanut) and only a modest decrease in the percentage of particles that enter the lungs [27, 28]. Further, Penicillium spores are only 2 microns in diameter. Thus, they have $1 / 1000^{\text {th }}$ of the volume of a 20 micron sphere. Taking values from the task force on lung dynamics [28], we calculate that you would have to inhale at least 100 small fungal spores to get the same quantity of allergen into the lungs as a pollen grain or a mite fecal particle.

\section{The mouse model}

Though most would argue that the mouse model of asthma in no way provides an adequate representation of severe asthma, this model has come to dominate publications about the mechanism by which allergens contribute to asthma [29, 30]. The protocol involves first sensitizing the mouse and then introducing a foreign protein (usually ovalbumin) into the lungs. Because of the physiology of the mouse lungs and the truly enormous relative quantities of foreign antigen used to challenge the mice, the model cannot provide any information about the factors that contribute to severity of asthma. In particular, it is not possible to compare the twitching of the mouse lungs during methacholine challenge with chronic BHR in humans that takes months to reverse [5, 6]. Challenge of a mouse with 100 $\mu \mathrm{l}$ of $1 \%$ ovalbumin represents about $100 \mu \mathrm{g}$ or at least five years of natural exposure to mite allergen for a human. Although the mouse model allows remarkably elegant dissection of the immunological events occurring in the mouse lungs, it is unwise to relate these findings to human disease except in the most general way.

\section{Relationships between chronic inhalant exposure and a) general severity and b) acute episodes induced by rhinovirus}

Simple examples of prolonged elevated allergen exposure include mite or mold-allergic patients living in a damp house or basement apartment, cat-allergic patients who move into an apartment that has high levels of allergen because the previous owner kept cats, and grass pollen-allergic subjects who keep their windows open to create a breeze. Interestingly, public knowledge about dust mites has altered houses so as to reduce conditions for mite growth. Thus, it is common knowledge that polished floors and regular hot washing of bedding is useful to reduce mite exposure. Some estimates of data from the Netherlands suggest that mite allergen levels in houses are almost ten-fold lower than they were when assays first became available (Fritz Spieksma and Rob Aalberse, personal communications). It is important to identify acute exacerbations of asthma that are caused by increased 
exposure because it is important to ensure that these patients receive adequate education about methods of controlling or avoiding exposure.

Among children being admitted to the hospital for acute exacerbations, a large proportion (i.e., $\mathbf{2 8 5 \%}$ ) are allergic, but only a minority (perhaps $10 \%$ ) have had chronically severe disease [31]. Thus, there is a major question about what causes the acute exacerbations. Transient increases in exposure are not a convincing explanation of most attacks. By contrast, there is extensive evidence that rhinoviruses can trigger or cause an acute attack of asthma [10-13]. The important thing here is that almost all the evidence about the effects of rhinovirus relates to allergic patients. This evidence comes both from studies on exacerbations of asthma and challenge studies [32-35]. Using both culture and PCR techniques to study patients presenting to the hospital, it has consistently been shown that the combination of rhinovirus infection and allergy is associated with the risk of asthma [10-13]. Furthermore, in a recent study of children in Costa Rica, we found that the combination of high titer IgE antibodies to dust mite and positive PCR for rhinovirus had the highest risk for asthma (odds ratio of 30, p<0.001) [36]. In that study, having a positive PCR for rhinovirus was only significantly associated with acute asthma among children who were allergic to dust mite allergens.

Challenge studies also show that the impact of rhinovirus on the lungs is restricted to allergic individuals. Several groups have reported that challenge of non-allergic individuals does not produce a response in the lungs [37, 38]. Busse and his colleagues in Madison showed that rhinovirus challenge of individuals with allergic rhinitis increased the inflammatory response of the lungs to subsequent segmental exposure to relevant allergen $[32,39]$. In studies on patients with mild asthma, the results have shown a response of the lungs in one-third to a half of the cases. In our study with Rhinovirus 16, there was a striking difference between the response of subjects with a total $\mathrm{IgE}>300 \mathrm{IU} / \mathrm{ml}$ and those with lower total IgE [35]. However, the group with higher IgE also had elevated exhaled nitric oxide (eNO), elevated eosinophil counts, and elevated nasal eosinophil cationic protein (ECP). Thus, at present it is not clear whether it is $\operatorname{IgE}$ per se or the inflammation that results from allergen exposure of an allergic subject that creates the risk of a reaction in the lungs to rhinovirus.

Further information has come from controlled trials using omalizumab (anti-IgE) to treat severe or moderately severe asthma [40,41]. In those studies, the treatment decreases free $\operatorname{IgE}$ as well as IgE on basophils and mast cells and eosinophilic inflammation [42, 43]. Indeed, the controlled trial of omalizumab used to treat inner city children had a striking effect in controlling the increase in acute episodes of asthma that occurred in May and September [40, 41]. Those months coincide with the seasons for which allergen exposure is highest which in combination with RV exposure is thought to be the leading cause of exacerbations. At present, the results from the inner city asthma trial do not answer whether the effect of treatment with anti-IgE is to decrease IgE on basophils and mast cells or to decrease "inflammation" associated with allergy and RV. As mentioned above, during experimental RV challenge, patients with higher IgE levels ( $>300)$ have significant changes in bronchial hyperreactivity as judged by methacholine testing and increased symptom severity. It seems likely that controlled trials of anti-IgE treatment prior to RV challenge will be needed to understand the interaction between allergy and RV.

\section{The relevance of fungal allergens to severe asthma}

There is a striking discrepancy between the willingness of physicians to prescribe broadspectrum antibiotics and the general reluctance of physicians treating asthma to consider systemic antifungal treatment. Given that patients with severe asthma, especially in 
conjunction with sinusitis, are treated routinely with both steroids and antibiotics, it should be no surprise that these patients are prone to excessive growth of yeast species both in the mouth and in the lungs.

There are three distinct forms of "exposure" to fungal allergens which have been associated with severe asthma (Table 1):

i. Fungal colonization of the lungs, most often with Aspergillus and in conjunction with immediate hypersensitivity to the relevant fungus.

ii. Inhalation of fungal allergens on spores or hyphae acting in the same way as other inhaled allergens.

iii. Fungal infection outside the respiratory tract again associated with immediate hypersensitivity and most often dermatophyte infection of the skin or nails.

The evidence for these different forms of asthma comes either from association studies or from controlled trials of treatment.

\section{Allergic bronchopulmonary aspergillosis (ABPA) and allergic bronchopulmonary mycosis (ABPM)}

The classical form of ABPA is well recognized and has clear criteria for diagnosis, which include: increased severity of asthma, transient infiltrates in the lungs, sputum production, elevated total $\mathrm{IgE}$ ( $\geq 400 \mathrm{IU} / \mathrm{ml}$ ), immediate hypersensitivity to Aspergillus, and eosinophilia ( 2500 AEC) $[14,44]$. These criteria generally do not include demonstration by culture of the fungus in the lungs; however, many physicians would prefer to establish the presence of the fungus in the lungs, using bronchoscopy if necessary, and also to establish the in vitro sensitivity of the fungus to antifungal drugs. A major feature of the first controlled trial of itraconazole for ABPA was that those patients whose cultured Aspergillus was shown to be sensitive to this drug in vitro responded better to treatment [18]. In practice, a major clue about Aspergillus often comes from the color of the sputum; thus, red, brown, orange, amber, or grey sputum should always be considered as a reason for evaluating possible fungal colonization of the lungs. In addition, the sputum is often described as sticky or tenacious.

Fungi of the Aspergillus genus are not susceptible to griseofulvin, nystatin, or fluconazole; thus, systemic oral treatment was not available before the introduction of itraconazole. This antifungal has now been used in two major controlled trials of treatment in severe asthma. The first, by Stevens and his colleagues in the United States, focused specifically on ABPA with strict criteria for enrollment [18]. The second, from the UK, used itraconazole to treat subjects with severe asthma and fungal sensitivity without focusing on evidence that the fungus was growing in the lungs [19]. Both trials reported successful outcomes, providing strong evidence that fungi growing on the patient can be an important contributing cause of severe asthma. We are well aware that the mechanism of imidazole (e.g., fluconazole, itraconazole) action may be related to the anti-inflammatory nature of these medications [45, 46]. It is also important to recognize the side effects of these medications including liver enzyme derangements and adrenal suppression $[47,48]$. In practice, there are two other drugs that can be used to treat Aspergillus (or other fungi) in the lungs. These are oral voriconazole and inhaled nebulized amphotericin B [49-51]. Oral voriconazole may be more effective than itraconazole in some patients because of wide specificity, but also because it is absorbed better. Nebulized amphotericin B has been used on an occasional basis for many years, particularly to treat Aspergillus in the lungs of patients with cystic fibrosis [50, 51]. It has also been used successfully in adult patients with asthma and COPD who get fungus in their lungs (Table 2). Although nebulized amphotericin B is irritating to the lungs and 
should be initiated with care, it is a very effective antifungal and does not give rise to the renal and bone marrow problems that are such an issue with intravenous amphotericin B.

There are two variants of fungal colonization in the lungs, which together may be as important as the classical cases of ABPA: firstly, infection of the lungs with a fungus other than Aspergillus (i.e., ABPM), and secondly, forme fruste ABPA or ABPM [14]. Several different fungi have been reported to cause ABPM, including Candida species and Curvularia [52, 53]. More common are the many cases of severe asthma where fungus is present in the lungs of a patient with severe asthma or intractable coughing, but who do not have the full features of ABPA or ABPM (Table 2). These include cases of COPD who wheeze and cough, but are not truly asthmatic and do not have immediate hypersensitivity to the fungus. Equally significant are the patients who present with increased severity of asthma and increased production of yellow mucus. These patients often report that the sputum is sticky or that it includes "worms" which are soft casts. The most common fungus found in these cases is Candida, which can be demonstrated by repeated culture of either the sputum or bronchoalveolar lavage (BAL) fluid. In addition, many of these cases have immediate hypersensitivity skin tests or IgE (usually low-titer) to $C$. albicans. Although there are no controlled trials of antifungal treatment in these cases, personal and reported experience with these cases using fluconazole or itraconazole has been successful in many instances. More research is needed to fully elucidate the role of candida in ABPM and severe asthma.

\section{Inhaled fungal allergens: Alternaria}

Although dozens of different fungi have been associated with asthma, the primary evidence about a relationship to severity relates to Alternaria [54-56]. The important features of the data on this fungus are that i) sensitivity to this fungus is associated with asthma in countries where the spores are known to be an important part of airborne fungal spores, ii) Alternaria sensitivity has shown up repeatedly in relation to severity, and iii) seasonal variation in severity has been reported [54-56]. The spores of Alternaria are large (i.e., $10 \times 14 \mu \mathrm{m}$ ) and could carry sufficient allergen to cause local foci of inflammation in the lungs. On the other hand, Alternaria growth in the lungs has not been reported. Occasionally other inhaled fungi such as Cladosporium or Penicillium appear to play an important role in severe asthma. Aspergillus is always considered to act either as an inhalant or as a colonizing organism. In terms of treatment, there are no convincing trials of avoidance of Alternaria, which is primarily an outdoor allergen but can certainly be found indoors. Although Alternaria is often included in immunotherapy regimes in patients with asthma in the US, there are no controlled trials to establish the efficacy of this approach in patients with severe asthma.

\section{Dermatophytes and asthma}

In the 1930s, Sulzberger was the first to propose that immediate hypersensitivity to dermatophytes in patients with infection of their toenails or skin could be a cause of allergic disease [57]. He provided evidence in relation to asthma, sinusitis, rhinitis, and urticaria. In 1985, we published a RAST assay for measuring IgE antibodies to allergens of Trichophyton species [58]. We reported positive results in patients with severe asthma, sinusitis, urticaria, and "idiopathic" anaphylaxis [58, 59]. When fluconazole became available, Ward et al. carried out a controlled trial of oral fluconazole in treating steroiddependent asthma [59]. That study demonstrated clinical improvement, decreased steroid use, and decreased sensitivity of the lungs to Trichophyton [59]. There have been many other reports of the association between Trichophyton sensitivity and asthma, including a striking report from Japan, which also showed a connection between higher titer IgE antibodies to Trichophyton and severity of asthma [20,60,61]. Further progress in this area 
would require a multicenter controlled trial of the use of itraconazole to treat dermatophyte infection in cases of severe asthma [62].

\section{Sinusitis and the potential role of bacteria}

Bacteria have been proposed to play a role in asthma in two ways: first, as a source of foreign antigen in the sinuses, and second, as a colonizing organism in the lungs. The case for bacteria as a source of foreign antigen or allergen was proposed by many allergists, in some cases before the development of antibiotics. Oscar Swineford, Jr. argued that both pathogenic and non-pathogenic bacteria could be a source of foreign antigens [63]. Similarly, Philip Norman, at Johns Hopkins, published several papers on immediate hypersensitivity to bacterial allergens [64]. The primary treatment modality proposed was bacterial immunotherapy, which was never studied in a convincing controlled trial. With the arrival of antibiotics, most felt that the issue had been resolved; however, bacteria growing in the sinuses are never eradicated, at least in part because of the protective effects of biofilms [65]. Given that inflammation of the sinuses is significantly associated with eosinophilia and that there is good evidence that eosinophil precursors are generated within the inflamed tissues of the sinuses, it seems logical to ask what foreign antigen is inducing the eosinophil response $[66,67]$. If bacteria stimulate $\mathrm{T}$ cells to produce IL-5, then it is logical to ask whether non-pathogens such as coagulase-negative Staphylococci could be a source of the T cell antigen. In our studies, the single most common organism cultured from surgical samples of sinuses was coagulase-negative $S$. aureus [67]. Clearly, it would be very interesting to understand the T cell response to Staphylococcus antigens, including proteins as well as the toxins.

\section{Bacterial colonization and infection of the lungs as a cause of asthma}

While the lung was previously thought to be a sterile environment, the invention of Phylochip ${ }^{\circledR}$ technology now allows genotyping, via $16 \mathrm{~S}$ ribosomal structure, of a wide array of bacteria that were previously undefined because of the inability to culture these micro-organisms. A land mark study by Hilty, et al found increased rates of pathogenic proteobacteria in the airways of adults with asthma or COPD and in children with asthma when compared to controls [68]. However, that study did not associate microbial content of the lungs with asthma severity. More recently, Huang, et al utilized similar technology to show that a higher diversity of micro-organisms in the airway correlated with bronchial hyper-responsiveness [69]. Further evidence of an association between severe asthma and bacterial colonization during childhood was provided in a prospective study of a birth cohort in Copenhagen. Hypopharyngeal cultures of Streptococcus pneumoniae, Haemophilus influenzae, Moraxella catarrhalis, and Staphylococcus aureus were obtained from neonates, and diary cards for wheeze were followed for the first five years of life. Colonization with $S$. pneumoniae, $M$. catarrhalis, $H$. influenzae, or a combination of these organisms was significantly associated with persistent wheeze, acute severe exacerbation of wheeze, and hospitalization for wheeze suggesting causation [70]. While these studies are important regarding the presence of these bacteria in the lungs of asthmatics, the relevance of these bacteria and the functional role that these micro-organisms play in severe asthma remains to be seen.

Reports that Chlamydia or Mycoplasma in the lungs could be a cause of asthma have come from several sources [71-73]. Overall, the evidence that these organisms provide antigens that contribute to asthma remains confusing. According to a review article by Johnston and Martin, Chlamydia and Mycoplasma may, in fact, have some relevance in acute asthma exacerbations. Nine of the twelve studies included in that review supported a relationship between infection with these organisms and asthma. The problem lies in the ability to accurately diagnose these pathogens [74]. A major study using ten days treatment with 
telithromycin for patients who had recently been treated in an emergency room showed a moderate benefit. However, although $61 \%$ of the subjects had serologic evidence of infection with bacteria that should be sensitive to this treatment, the response to therapy did not correlate with bacteriologic status [72].

\section{Vocal cord dysfunction (VCD) and other forms of upper airway dysfunction}

VCD has been recognized for 20 years and is clearly an important cause of severe symptoms that are easily confused with other forms of asthma $[31,75]$. Using a traditional definition of asthma, such as "obstruction of airflow from the lungs that is reversible both with time and in response to treatment," VCD is a form of asthma. On the other hand, defining asthma as "reversible airway obstruction caused by eosinophilic inflammation of the bronchi," VCD must be considered a different disease. What matters here is that many cases of VCD (i.e., those cases where changes in the upper airways alone are responsible for the symptoms) have no evidence of inflammation and no evidence that allergens play a role [76]. In other cases of VCD, the changes in the upper airways develop as a complication of asthma involving the lower airways. These cases are particularly difficult to treat, because it is often unclear whether they are breathless because of upper airway movements or because of lung inflammation. Thus, although it is a mistake to fail to identify VCD and treat it appropriately, it is equally problematic to assume that because the vocal cords are paradoxically closing, the bronchi are not also inflamed. In these cases, complete absence of allergy, an eosinophil count $<200$, normal eNO, and a low score for CT scan of the sinuses (i.e., <3) can provide strong evidence against inflammation in the respiratory tract $[67,76]$.

\section{Obesity and asthma}

The diagnosis of asthma in obese individuals remains a challenge. Determining the roles of bronchial hyperreactivity versus general decompensation in the breathless obese patient is important. In many classification systems, continued shortness of breath either at rest or with exercise while taking intermediate or high doses of inhaled steroids would define a patient as having moderate to severe asthma. Accurate measurements of lung physiology, defining the role of allergy, and attempting to ascertain markers for inflammation including exhaled nitric oxide are paramount in the obese patient [16].

Whether the inflammatory milieu associated with obesity influences bronchial hyperreactivity (BHR) is a matter of much debate. Shore and Fredburg showed increased leptin levels in the obese mouse lead to increased BHR [77, 78]. Alternatively, in a study of 136 asthmatic adults performed by van Veen, et al, body mass index (BMI) was inversely related to both sputum eosinophils and expired nitric oxide in a study [79]. Subsequent work performed by Rastogi and colleagues suggested that obesity-associated asthma was characterized by Th1 polarization of $\mathrm{T}$ cells suggesting a much different phenotype than previously reported in atopic asthmatics. In that study of 120 children, the altered Th1 environment (higher IFN- $\gamma$ in response to phorbol 12-myristate 13-acetate (PMA) and tetanus toxoid) inversely correlated to lung function. Interestingly, $\mathrm{T}$ cell responses observed in obese asthmatics were not different from those seen in obese non-asthmatics [80].

More recently, there has been data suggesting two distinct phenotypes of obese patients with asthma, those with late and early onset asthma. The early onset asthmatics tended to have higher IgE levels, and they were more atopic. Those patients were more likely atopic, allergic asthmatics who just happen to be obese. The late onset overweight asthmatics were generally non-atopic leading one to conclude that this type of asthma occurs in the setting of obesity [81]. 
The central problem with diagnosis of asthma in obesity remains first being sure that the patients have lung inflammation, and second that the breathlessness is truly due to airflow obstruction in the lung. In terms of treatment, all obese subjects need an exercise regime, and it is important to make sure that a diagnosis of asthma, correct or not, does not interfere with exercise.

\section{Conclusions}

Because severe adult onset or intrinsic asthma was originally defined as "non-allergic," it is often implied that severe asthma is less allergic than chronic asthma. However, this depends more than anything on how the cases are defined. Allergy is a major feature of asthma presenting to the hospital; equally, allergy is a dominant feature of exercise-induced bronchospasm (EIB), which can be severe. However, with the wide availability and use of high dose inhaled steroids, a large proportion of cases of allergic asthma that would otherwise be moderately severe or severe can be controlled. This has led to a major change in the distribution of cases presenting to specialist clinics. Our recent data argue strongly that the titer of IgE antibodies is relevant to severe allergic asthma and, in particular, the risk of exacerbations after a rhinovirus infection.

There are several aspects of the relationship between IgE antibodies to inhalant allergens and asthma that need clarification:

i. To what degree is severity, both chronic and acute, related to the titer of specific IgE antibodies?

ii. Does the effect of treatment with anti-IgE depend on decreasing inflammation, or is it directly dependent upon the concentration of IgE on mast cells or basophils?

iii. Can the effects of anti-IgE treatment be demonstrated in rhinovirus challenge studies?

iv. Are the currently available indirect markers of inflammation in the respiratory tract adequate?

With the availability of fluconazole and itraconazole, it has become much easier to recommend and to investigate the use of systemic antifungal treatment. There is now good evidence from controlled trials to support the use of this treatment in ABPA, but also in less well-defined cases where fungal sensitization is involved [19]. Clearly, more evidence is needed about the relevance of dermatophyte infection and about the need to treat forme fruste ABPA or ABPM. Perhaps three questions could focus the need for further study in relation to fungal infection:

i. Should culture of bronchial washings for fungi be a routine part of the management of severe asthma?

ii. Is it necessary to obtain information about the sensitivity of fungal organisms before starting treatment?

iii. Are there better approaches using nebulized antifungals, particularly itraconazole or even amphotericin B, that would make it possible to treat with fewer side effects?

Late onset or intrinsic asthma in adults is often relatively non-allergic, as judged by skin tests to common inhalant allergens; however, these cases are often characterized by eosinophilia and sinusitis. The question is whether a foreign antigen is responsible for the eosinophilia. The obvious choices for a foreign antigen (after the inhalant allergens) are fungal or bacterial proteins. However, in many of these cases, there is little evidence for $\operatorname{IgE}$ responses, which raises the old question of whether there are cases of asthma caused by a 
Th2 response to a foreign antigen without IgE antibodies. That $\mathrm{T}$ cells are involved in asthma is clear from the extensive experiments on T cell responses to Fel d 1 peptides [82, 83]. However, all of those studies are done on patients with IgE antibodies to Fel $\mathrm{d} 1$. There is a need to identify the specificity of T cells producing IL-5 in patients with "non-allergic" but eosinophilic asthma.

Finally, we would stress that any approach to managing severe asthma or to defining the relevance of allergy depends upon careful classification of the cases. It is obvious that exacerbation-prone patients with IgE antibody titers to dust mite, cat, or cockroach allergen of over $17.5 \mathrm{IU} / \mathrm{ml}$ (class 4) need to be identified. Equally, the approach to treatment in cases of ABPA or dermatophyte infection is an area that needs specialist involvement. Although VCD is now well recognized, the formal diagnosis and the treatment of these cases is not satisfactory. There are still cases receiving oral steroids where there is no evidence of inflammation. Clearly, these distinctions require evaluations of lung function, monitoring for evidence of inflammation in the respiratory tract, and, also, appropriate tests of allergy. In cases where the severity reflects ongoing mucus production and bronchospasm within the lungs not responding to treatment except oral steroids, the use of bronchoscopy to evaluate organisms in the lungs should also be considered.

\section{Acknowledgments}

The authors would like to acknowledge Hayley James for her help with manuscript preparation.

Disclosures: Unpublished work performed by the authors on the prevalence of rhinovirus infections and allergy in Costa Rica was funded by the Cove Point Foundation and supported by grants NIH AI-20565 and 5T32 AI007496-17 as well as support from the University of Virginia Children's Hospital Grant-in-Aid fund.

Thomas A.E. Platts-Mills is a consultant for Phadia, Inc. and has received funding from them for unrelated research. Peter Heymann is the recipient of an investigator initiated grant from Novartis.

\section{References}

1. Tovey ER, Chapman MD, Platts-Mills TA. Mite faeces are a major source of house dust allergens. Nature. 1981; 289:592-3. [PubMed: 7464922]

2. Platts-Mills, TAE.; Mitchell, EB.; Tovey, ER.; Chapman, MD.; Wilkins, SR. Airborne allergen exposure, allergen avoidance and bronchial hyperreactivity. In: Kay, AB.; Austen, KF.; Lichtenstein, LM., editors. Asthma: physiology, immunopharmacology and treatment, Third International Symposium. London: Academic Press; 1984. p. 297-314.

3. Platts-Mills TAE, de Weck AL, Aalberse RC, et al. Dust mite allergens and asthma -- a worldwide problem. J Allergy Clin Immunol. 1989; 83:416-27. [PubMed: 2645343]

4. Altounyan RE. Review of clinical activity and mode of action of sodium cromoglycate. Clin Allergy. 1980; (10):481-9.

5. Platts-Mills TA, Tovey ER, Mitchell EB, Moszoro H, Nock P, Wilkins SR. Reduction of bronchial hyperreactivity during prolonged allergen avoidance. Lancet. 1982; 2:675-8. [PubMed: 6126624]

6. Kerrebijn, K. Endogenous factors in childhood CNSLD: methodological aspects in population studies. The Netherlands: Royal Vangorcum Assesn; 1970. p. 38-48.

7. Fitzpatrick AM, Gaston BM, Erzurum SC, Teague WG. Features of severe asthma in school-age children: Atopy and increased exhaled nitric oxide. J Allergy Clin Immunol. 2006; 118:1218-25. [PubMed: 17157650]

8. Expert Panel Report 3 (EPR-3). Guidelines for the Diagnosis and Management of Asthma-Summary Report 2007. J Allergy Clin Immunol. 2007; 120:S94-138. [PubMed: 17983880]

9. Reddel HK, Taylor DR, Bateman ED, et al. An official American Thoracic Society/European Respiratory Society statement: asthma control and exacerbations: standardizing endpoints for clinical asthma trials and clinical practice. Am J Respir Crit Care Med. 2009; 180:59-99. [PubMed: 19535666] 
10. Duff AL, Pomeranz ES, Gelber LE, et al. Risk factors for acute wheezing in infants and children: viruses, passive smoke, and IgE antibodies to inhalant allergens. Pediatrics. 1993; 92:535-40. [PubMed: 8414823]

11. Rakes GP, Arruda E, Ingram JM, et al. Rhinovirus and respiratory syncytial virus in wheezing children requiring emergency care. IgE and eosinophil analyses. Am J Respir Crit Care Med. 1999; 159:785-90. [PubMed: 10051251]

12. Heymann PW, Carper HT, Murphy DD, et al. Viral infections in relation to age, atopy, and season of admission among children hospitalized for wheezing. J Allergy Clin Immunol. 2004; 114:239_ 47. [PubMed: 15316497]

13. Murray CS, Poletti G, Kebadze T, et al. Study of modifiable risk factors for asthma exacerbations: virus infection and allergen exposure increase the risk of asthma hospital admissions in children. Thorax. 2006; 61:376-82. [PubMed: 16384881]

14. Fairs A, Agbetile J, Hargadon B, et al. IgE sensitization to Aspergillus fumigatus is associated with reduced lung function in asthma. Am J Respir Crit Care Med. 2010; 182:1362-8. [PubMed: 20639442]

15. Beuther DA, Weiss ST, Sutherland ER. Obesity and asthma. Am J Respir Crit Care Med. 2006; 174:112-9. [PubMed: 16627866]

16. Shim YM, Herring RC, Burnett A, et al. Cardiopulmonary exercise physiology among obese adolescents with or without a diagnosis of asthma. preparation. 2011

17. Platts-Mills TA, Vervloet D, Thomas WR, Aalberse RC, Chapman MD. Indoor allergens and asthma: report of the Third International Workshop. J Allergy Clin Immunol. 1997; 100:S2-24. [PubMed: 9438476]

18. Stevens DA, Schwartz HJ, Lee JY, et al. A randomized trial of itraconazole in allergic bronchopulmonary aspergillosis. N Engl J Med. 2000; 342:756-62. [PubMed: 10717010]

19. Denning DW, O'Driscoll BR, Powell G, et al. Randomized controlled trial of oral antifungal treatment for severe asthma with fungal sensitization: The Fungal Asthma Sensitization Trial (FAST) study. Am J Respir Crit Care Med. 2009; 179:11-8. [PubMed: 18948425]

20. Ward GW Jr, Woodfolk JA, Hayden ML, Jackson S, Platts-Mills TA. Treatment of late-onset asthma with fluconazole. J Allergy Clin Immunol. 1999; 104:541-6. [PubMed: 10482825]

21. Cowan DC, Cowan JO, Palmay R, Williamson A, Taylor DR. Effects of steroid therapy on inflammatory cell subtypes in asthma. Thorax. 2010; 65:384-90. [PubMed: 19996343]

22. Malerba M, Ragnoli B, Radaeli A, Tantucci C. Usefulness of exhaled nitric oxide and sputum eosinophils in the long-term control of eosinophilic asthma. Chest. 2008; 134:733-9. [PubMed: 18842911]

23. Wenzel SE, Schwartz LB, Langmack EL, et al. Evidence that severe asthma can be divided pathologically into two inflammatory subtypes with distinct physiologic and clinical characteristics. Am J Respir Crit Care Med. 1999; 160:1001-8. [PubMed: 10471631]

24. Killian D, Cockcroft DW, Hargreave FE, Dolovich J. Factors in allergen-induced asthma: relevance of the intensity of the airways allergic reaction and non-specific bronchial reactivity. Clin Allergy. 1976; 6:219-25. [PubMed: 939034]

25. Cockcroft DW, Hargreave FE, O'Byrne PM, Boulet LP. Understanding allergic asthma from allergen inhalation tests. Can Respir J. 2007; 14:414-8. [PubMed: 17948142]

26. Tovey ER, Chapman MD, Wells CW, Platts-Mills TA. The distribution of dust mite allergen in the houses of patients with asthma. Am Rev Respir Dis. 1981; 124:630-5. [PubMed: 7305119]

27. Svartengren M, Falk R, Linnman L, Philipson K, Camner P. Deposition of large particles in human lung. Exp Lung Res. 1987; 12:75-88. [PubMed: 3102217]

28. Bates DV, Fish BR, Hatch TF, Mercer TT, Morrow PE. Deposition and retention models for internal dosimetry of the human respiratory tract. Task group on lung dynamics. Health Phys. 1966; 12:173-207. [PubMed: 5916786]

29. Yu M, Tsai M, Tam SY, Jones C, Zehnder J, Galli SJ. Mast cells can promote the development of multiple features of chronic asthma in mice. J Clin Invest. 2006; 116:1633-41. [PubMed: 16710480]

30. Spergel JM, Mizoguchi E, Brewer JP, Martin TR, Bhan AK, Geha RS. Epicutaneous sensitization with protein antigen induces localized allergic dermatitis and hyperresponsiveness to methacholine 
after single exposure to aerosolized antigen in mice. J Clin Invest. 1998; 101:1614-22. [PubMed: 9541491]

31. Ayres JG, Mansur AH. Vocal cord dysfunction and severe asthma: considering the total airway. Am J Respir Crit Care Med. 2011; 184:2-3. [PubMed: 21737588]

32. Lemanske RF Jr, Dick EC, Swenson CA, Vrtis RF, Busse WW. Rhinovirus upper respiratory infection increases airway hyperreactivity and late asthmatic reactions. J Clin Invest. 1989; 83:110. [PubMed: 2536042]

33. Halperin SA, Eggleston PA, Beasley P, et al. Exacerbations of asthma in adults during experimental rhinovirus infection. Am Rev Respir Dis. 1985; 132:976-80. [PubMed: 2998246]

34. Papadopoulos NG, Papi A, Psarras S, Johnston SL. Mechanisms of rhinovirus-induced asthma. Paediatr Respir Rev. 2004; 5:255-60. [PubMed: 15276138]

35. Zambrano JC, Carper HT, Rakes GP, et al. Experimental rhinovirus challenges in adults with mild asthma: response to infection in relation to IgE. J Allergy Clin Immunol. 2003; 111:1008-16. [PubMed: 12743565]

36. Soto-Quiros M, Avila L, Carper HT, Murphy DD, James HR, Heymann PW. Rhinovirus infections and biomarkers of airway inflammation. preparation. 2011

37. Summers QA, Higgins PG, Barrow IG, Tyrrell DA, Holgate ST. Bronchial reactivity to histamine and bradykinin is unchanged after rhinovirus infection in normal subjects. Eur Respir J. 1992; 5:313-7. [PubMed: 1572444]

38. de Kluijver J, Grunberg K, Sont JK, et al. Rhinovirus infection in nonasthmatic subjects: effects on intrapulmonary airways. Eur Respir J. 2002; 20:274-9. [PubMed: 12212955]

39. Calhoun WJ, Dick EC, Schwartz LB, Busse WW. A common cold virus, rhinovirus 16, potentiates airway inflammation after segmental antigen bronchoprovocation in allergic subjects. J Clin Invest. 1994; 94:2200-8. [PubMed: 7989575]

40. Milgrom H, Fick RB Jr, Su JQ, et al. Treatment of allergic asthma with monoclonal anti-IgE antibody. rhuMAb-E25 Study Group. N Engl J Med. 1999; 341:1966-73. [PubMed: 10607813]

41. Busse WW, Morgan WJ, Gergen PJ, et al. Randomized trial of omalizumab (anti-IgE) for asthma in inner-city children. N Engl J Med. 2011; 364:1005-15. [PubMed: 21410369]

42. Djukanovic R, Wilson SJ, Kraft M, et al. Effects of treatment with anti-immunoglobulin E antibody omalizumab on airway inflammation in allergic asthma. Am J Respir Crit Care Med. 2004; 170:583-93. [PubMed: 15172898]

43. Eckman JA, Sterba PM, Kelly D, et al. Effects of omalizumab on basophil and mast cell responses using an intranasal cat allergen challenge. J Allergy Clin Immunol. 2010; 125:889-95. e7. [PubMed: 19962744]

44. Knutsen AP, Slavin RG. Allergic bronchopulmonary aspergillosis in asthma and cystic fibrosis. Clin Dev Immunol. 2011; 2011:843763. [PubMed: 21603163]

45. Steel HC, Theron AJ, Tintinger GR, Anderson R. Posaconazole attenuates leukotriene B4 release and uptake of calcium by chemoattractant-activated human neutrophils: a potential strategy to control neutrophil-mediated inflammation. J Antimicrob Chemother. 2009; 64:1008-12. [PubMed: 19744985]

46. Steel HC, Tintinger GR, Anderson R. Comparison of the anti-inflammatory activities of imidazole antimycotics in relation to molecular structure. Chem Biol Drug Des. 2008; 72:225-8. [PubMed: 18924285]

47. Parmar JS, Howell T, Kelly J, Bilton D. Profound adrenal suppression secondary to treatment with low dose inhaled steroids and itraconazole in allergic bronchopulmonary aspergillosis in cystic fibrosis. Thorax. 2002; 57:749-50. [PubMed: 12149540]

48. Skov M, Main KM, Sillesen IB, Muller J, Koch C, Lanng S. Iatrogenic adrenal insufficiency as a side-effect of combined treatment of itraconazole and budesonide. Eur Respir J. 2002; 20:127-33. [PubMed: 12166560]

49. Patterson K, Strek ME. Allergic bronchopulmonary aspergillosis. Proc Am Thorac Soc. 2010; 7:237-44. [PubMed: 20463254]

50. Proesmans M, Vermeulen F, Vreys M, De Boeck K. Use of nebulized amphotericin B in the treatment of allergic bronchopulmonary aspergillosis in cystic fibrosis. Int J Pediatr. 2010; 2010:376287. [PubMed: 21234103] 
51. Kuiper L, Ruijgrok EJ. A review on the clinical use of inhaled amphotericin B. J Aerosol Med Pulm Drug Deliv. 2009; 22:213-27. [PubMed: 19466905]

52. Gonzalez de Olano D, Gonzalez-Mancebo E, Gandolfo Cano M, et al. Successful treatment of allergic bronchopulmonary candidiasis with a recombinant anti-immunoglobulin E antibody. $\mathrm{J}$ Investig Allergol Clin Immunol. 2009; 19:416-7.

53. Halwig JM, Brueske DA, Greenberger PA, Dreisin RB, Sommers HM. Allergic bronchopulmonary curvulariosis. Am Rev Respir Dis. 1985; 132:186-8. [PubMed: 4040344]

54. O'Hollaren MT, Yunginger JW, Offord KP, et al. Exposure to an aeroallergen as a possible precipitating factor in respiratory arrest in young patients with asthma. N Engl J Med. 1991; 324:359-63. [PubMed: 1987459]

55. O'Driscoll BR, Powell G, Chew F, et al. Comparison of skin prick tests with specific serum immunoglobulin $\mathrm{E}$ in the diagnosis of fungal sensitization in patients with severe asthma. Clin Exp Allergy. 2009; 39:1677-83. [PubMed: 19689458]

56. Halonen M, Stern DA, Wright AL, Taussig LM, Martinez FD. Alternaria as a major allergen for asthma in children raised in a desert environment. Am J Respir Crit Care Med. 1997; 155:135661. [PubMed: 9105079]

57. Wise F, Sulzberger MB. Urticaria and hay fever due to Trichophyton (Epidermophyton interdigital). JAMA. 1930:1504-8.

58. Platts-Mills TA, Fiocco GP, Hayden ML, Guerrant JL, Pollart SM, Wilkins SR. Serum IgE antibodies to Trichophyton in patients with urticaria, angioedema, asthma, and rhinitis: development of a radioallergosorbent test. J Allergy Clin Immunol. 1987; 79:40-5. [PubMed: 3805546]

59. Ward GW Jr, Karlsson G, Rose G, Platts-Mills TA. Trichophyton asthma: sensitisation of bronchi and upper airways to dermatophyte antigen. Lancet. 1989; 1:859-62. [PubMed: 2564948]

60. Matsuoka H, Niimi A, Matsumoto H, et al. Specific IgE response to trichophyton and asthma severity. Chest. 2009; 135:898-903. [PubMed: 19188557]

61. Platts-Mills TA, Woodfolk JA. Trichophyton asthma. Chest. 2009; 135:887-8. [PubMed: 19349392]

62. Hope WW, Billaud EM, Lestner J, Denning DW. Therapeutic drug monitoring for triazoles. Curr Opin Infect Dis. 2008; 21:580-6. [PubMed: 18978525]

63. Swineford, O, Jr. Asthma and hay fever. Springfield, IL: Charles C Thomas; 1971.

64. Goshi K, Cluff LE, Norman PS. Studies on the pathogenesis of staphylococcal infection. V. Purification and characterization of staphylococcal alpha hemolysin. Bull Johns Hopkins Hosp. 1963; 112:15-30. [PubMed: 13949383]

65. Boles BR, Singh PK. Endogenous oxidative stress produces diversity and adaptability in biofilm communities. Proc Natl Acad Sci U S A. 2008; 105:12503-8. [PubMed: 18719125]

66. Denburg JA, Keith PK. Systemic aspects of chronic rhinosinusitis. Immunol Allergy Clin North Am. 2004; 24:87-102. [PubMed: 15062429]

67. Newman LJ, Platts-Mills TA, Phillips CD, Hazen KC, Gross CW. Chronic sinusitis. Relationship of computed tomographic findings to allergy, asthma, and eosinophilia. JAMA. 1994; 271:363-7. [PubMed: 8283586]

68. Hilty M, Burke C, Pedro H, et al. Disordered microbial communities in asthmatic airways. PLoS One. 2010; 5:e8578. [PubMed: 20052417]

69. Huang YJ, Nelson CE, Brodie EL. Airway microbiota and bronchial hyperresponsiveness in patients with suboptimally controlled asthma. J Allergy Clin Immunol. 2011; 127:372-81. e1-3. [PubMed: 21194740]

70. Bisgaard H, Hermansen MN, Buchvald F, et al. Childhood asthma after bacterial colonization of the airway in neonates. N Engl J Med. 2007; 357:1487-95. [PubMed: 17928596]

71. Sutherland ER, Martin RJ. Asthma and atypical bacterial infection. Chest. 2007; 132:1962-6. [PubMed: 18079229]

72. Johnston SL, Blasi F, Black PN, Martin RJ, Farrell DJ, Nieman RB. The effect of telithromycin in acute exacerbations of asthma. N Engl J Med. 2006; 354:1589-600. [PubMed: 16611950] 
73. Peters J, Singh H, Brooks EG, et al. Persistence of CARDS Toxin-producing Mycoplasma pneumoniae in Refractory Asthma. Chest. 2011

74. Johnston SL, Martin RJ. Chlamydophila pneumoniae and Mycoplasma pneumoniae: a role in asthma pathogenesis? Am J Respir Crit Care Med. 2005; 172:1078-89. [PubMed: 15961690]

75. Christopher KL, Wood RP 2nd, Eckert RC, Blager FB, Raney RA, Souhrada JF. Vocal-cord dysfunction presenting as asthma. N Engl J Med. 1983; 308:1566-70. [PubMed: 6406891]

76. Peters EJ, Hatley TK, Crater SE, Phillips CD, Platts-Mills TA, Borish L. Sinus computed tomography scan and markers of inflammation in vocal cord dysfunction and asthma. Ann Allergy Asthma Immunol. 2003; 90:316-22. [PubMed: 12669895]

77. Shore SA, Schwartzman IN, Mellema MS, Flynt L, Imrich A, Johnston RA. Effect of leptin on allergic airway responses in mice. J Allergy Clin Immunol. 2005; 115:103-9. [PubMed: 15637554]

78. Shore SA, Terry RD, Flynt L, Xu A, Hug C. Adiponectin attenuates allergen-induced airway inflammation and hyperresponsiveness in mice. J Allergy Clin Immunol. 2006; 118:389-95. [PubMed: 16890763]

79. van Veen IH, Ten Brinke A, Sterk PJ, Rabe KF, Bel EH. Airway inflammation in obese and nonobese patients with difficult-to-treat asthma. Allergy. 2008; 63:570-4. [PubMed: 18394131]

80. Rastogi D, Canfield SM, Andrade A, et al. Obesity-associated asthma in children- a distinct entity. Chest. 2011

81. Holguin F, Bleecker ER, Busse WW, et al. Obesity and asthma: an association modified by age of asthma onset. J Allergy Clin Immunol. 2011; 127:1486-93. e2. [PubMed: 21624618]

82. Haselden BM, Kay AB, Larche M. Immunoglobulin E-independent major histocompatibility complex-restricted T cell peptide epitope-induced late asthmatic reactions. J Exp Med. 1999; 189:1885-94. [PubMed: 10377184]

83. Reefer AJ, Carneiro RM, Custis NJ, et al. A role for IL-10-mediated HLA-DR7-restricted T celldependent events in development of the modified Th2 response to cat allergen. J Immunol. 2004; 172:2763-72. [PubMed: 14978075] 


\section{Table 1}

Classification of severe asthma: focusing on the relevance of specific foreign allergens or antigens.

I. Inhalant Allergens

\begin{tabular}{|c|c|}
\hline Perennial Indoor & - Dust mite, cat, dog, cockroach \\
\hline \multirow[b]{2}{*}{ Seasonal (usually outdoor) } & - Pollens: grass, tree, weed \\
\hline & - Fungal spores: Alternaria, Aspergillus, Cladosporium \\
\hline \multirow{3}{*}{ Causes of increased severity } & - Prolonged high exposure and high titer IgE ab \\
\hline & - Rhinovirus infection \\
\hline & - Exercise - usually too rapid onset \\
\hline \multicolumn{2}{|l|}{ II. Fungal Allergens } \\
\hline \multirow{2}{*}{ Growing in the lungs } & - ABPA: full syndrome and forme fruste ${ }^{\#}$ \\
\hline & - ABPM: full syndrome (rare) and forme fruste (common) \\
\hline \multirow[t]{2}{*}{ Dermatophytes } & - Trichophyton asthma (usually combined with severe sinusitis) \\
\hline & - Extensive sinusitis (score 220 ) with nasal polyps \\
\hline \multirow{2}{*}{$\begin{array}{l}\text { III.Samter's triad respiratory } \\
\text { disease) }\end{array}$} & - Aspirin sensitivity \\
\hline & $\begin{array}{l}\text { - Bacteria in the sinuses possibly acting as a foreign antigen driving a } \mathrm{T} \text { cell response without IgE } \\
\mathrm{ab}\end{array}$ \\
\hline
\end{tabular}

IV. Non-inflammatory

- Including VCD

- May include syndromes above and below the cords

Upper airway dysfunction

- Irritant or exercise-exacerbated

- Generally no evidence of inflammation or allergy

- Reduced lung function secondary to lung physiology

Obesityt

- Obese breathless children require careful evaluation to exclude deconditioning

${ }^{\#}$ Forme fruste includes cases without full criteria for ABPA [14]

*Breathlessness in obese teenagers may be related to deconditioning with no evidence of inflammation, allergy, or abnormalities of lung function $[15,16]$. 
Table 2

Six cases of severe asthma or intractable cough variant asthma involving fungal colonization and successfully treatment with antifungals.

\begin{tabular}{|c|c|c|c|c|}
\hline Patient Age/Sex & Diagnosis & Description & Treatment & Resolution \\
\hline $43 / \mathrm{F}$ & ABPM & $\begin{array}{l}\text { - Sinus disease with severe asthma } \\
\text { - Multiple courses of steroids } \\
\text { - Grew } C \text {. albicans from sinus tissue } \\
\text { and sputum } \\
\text { - Skin test for } C \text {. albicans ++ } \\
\text { - IgE ab } 2.8 \mathrm{IU} / \mathrm{ml} \text {; total IgE } 360 \mathrm{IU} / \\
\mathrm{ml}\end{array}$ & Fluconazole $100 \mathrm{mg}$ daily & $\begin{array}{l}\text { Complete } \\
\text { control - no } \\
\text { further steroids } \\
\text { for } 4 \text { years }\end{array}$ \\
\hline $68 / \mathrm{F}$ & $\begin{array}{l}\text { COPD colonized with } \\
\text { Aspergillus }\end{array}$ & $\begin{array}{l}\text { - Intractable coughing and wheezing } \\
\text { - Multiple hospitalizations } \\
\text { - }{ }^{*} \text { FEV1 } 37 \% \text { predicted; DLCO } \\
43 \% \text { predicted } \\
\text { - Skin tests negative; total IgE } 28 \\
\text { IU/ml } \\
\text { - BAL grew Aspergillus + }\end{array}$ & Nebulized amphotericin B & $\begin{array}{l}\text { Complete } \\
\text { control of cough } \\
\text { with no change } \\
\text { in lung function }\end{array}$ \\
\hline $62 / \mathrm{M}$ & Trichophyton asthma & $\begin{array}{l}\text { - Late-onset severe asthma; } \\
\text { hospitalized three times } \\
\text { - Extensive dermatophyte infection; } \\
\text { Skin test for Trichophyton ++ }\end{array}$ & $\begin{array}{l}\text { Fluconazole } 100 \mathrm{mg} \text { daily } \\
\text { for } 3 \text { years }\end{array}$ & $\begin{array}{l}\text { Cured - stayed } \\
\text { controlled for } 6 \\
\text { years }\end{array}$ \\
\hline $38 / \mathrm{F}$ & ABPM forme fruste & $\begin{array}{l}\text { - Chronic allergic asthma, more } \\
\text { severe over } 2 \text { years } \\
\text { - Total IgE } 220 \mathrm{IU} / \mathrm{ml} \\
\text { - Sputum soft casts, grew } C \text {. } \\
\text { albicans } \\
\text { - Skin test positive for mite, } \\
\text { cockroach, } C \text {. albicans }\end{array}$ & $\begin{array}{c}\text { Fluconazole } 100 \mathrm{mg} \text { every } \\
\text { other day }\end{array}$ & $\begin{array}{l}\text { Improved }(++) \\
\text { - no further oral } \\
\text { steroids }\end{array}$ \\
\hline $42 / \mathrm{F}$ & $\begin{array}{l}\text { Severe cough with } A \text {. } \\
\text { fumigatus in the lungs }\end{array}$ & $\begin{array}{l}\text { - Rapid onset of intractable } \\
\text { coughing with tenacious sputum; } \\
\text { unable to work } \\
\text { - Non-allergic; normal lung } \\
\text { function; eosinophilic with absolute } \\
\text { count of } 430 \\
\text { - BAL: Aspergillus ++ and } \\
\text { eosinophilia }\end{array}$ & Oral itraconazole & $\begin{array}{l}\text { Cough and } \\
\text { sputum cleared }\end{array}$ \\
\hline $65 / \mathrm{M}$ & ABPA plus nocardiosis & $\begin{array}{l}\text { - Severe asthma; continuous } \\
\text { wheezing and sputum production } \\
\text { despite } 50 \mathrm{mg} \text { prednisone/day } \\
\text { - BAL } \times 2 \text { grew Aspergillus and } \\
\text { Nocardia }\end{array}$ & $\begin{array}{l}\text { Itraconazole, followed by } \\
\text { prolonged voriconazole and } \\
\text { augmentin }\end{array}$ & $\begin{array}{l}\text { Off oral steroids } \\
\text { for } 5 \text { years }\end{array}$ \\
\hline
\end{tabular}

